\title{
PREVALENCE OF ASYMPTOMATIC BACTERIURIA IN PREGNANCY AT A TEACHING HOSPITAL
}

\author{
Indira Guntoory1, Narasinga Rao Tamaraba², Sarath Babu Rayapu ${ }^{3}$
}

${ }^{1}$ Associate Professor, Department of Obstetrics and Gynaecology, MIMS, Nellimarla, Vizianagaram.

2 Professor, Department of Obstetrics and Gynaecology, MIMS, Nellimarla, Vizianagaram.

${ }^{3}$ Professor, Department of Microbiology, MIMS, Nellimarla, Vizianagaram.

\begin{tabular}{l}
\hline ABSTRACT \\
BACKGROUND \\
UTI is the most frequent medical complication. It may be asymptomatic or symptomatic. Asymptomatic bacteriuria if left \\
untreated might result in symptomatic UTI and adverse pregnancy outcomes.
\end{tabular}

AIM

This prospective study was aimed to determine the prevalence of Asymptomatic bacteriuria of pregnancy among antenatal women attending the antenatal clinic in the Department of Obstetrics and Gynaecology, Maharajah's Institute of Medical Sciences, Nellimarla, Vizianagaram District, Andhra Pradesh.

\section{MATERIAL AND METHODS}

After taking approval from Institutional Ethics Committee and informed written consent from patients, urine samples were collected from antenatal women in their first antenatal visit. A clean catch midstream specimen of urine was collected and in oculated on blood agar and MacConkey's agar. It was incubated aerobically at 37 degrees centigrade overnight. Isolates were identified up to species level using standard protocol and sensitivity to different antibiotics is tested. Results were analysed statistically and a P value of less than 0.05 was taken as significant.

\section{RESULTS}

A total of 173 samples were screened; 154 women showed no growth on culture; 19 women had significant bacteriuria with a prevalence rate of 10.98\%; 15 women in the age group of 18-25 years and 4 women in the age group of 26-35 years had significant bacteriuria; 83 women were multiparous and 11 (57.89\%) women in this group had significant bacteriuria, while only 8 (42.1\%) out of 90 women in the nulliparous group had significant bacteriuria. With respect to trimester, 10 (52.63\%) out of 19 culture positive cases were in second trimester. In our study, the organisms isolated were Escherichia coli, Staphylococcus aureus and Klebsiella pneumoniae. The bacteria grown were most sensitive to Ampicillin+Sulbactam (68\%), Nitrofurantoin (73\%), Amikacin (84\%) and Meropenem (100\%).

\section{CONCLUSION}

It is therefore essential to screen every antenatal women for asymptomatic bacteriuria of pregnancy by a urine culture at least once on their first visit. Antenatal women should be educated about maintenance of personal and perineal hygiene to prevent faecal contamination of the urinary tract.

\section{KEYWORDS}

Asymptomatic Bacteriuria, UTI in Antenatal Women, Prevalence of UTI.

HOW TO CITE THIS ARTICLE: Guntoory I, Tamaraba NR, Rayapu SB. Prevalence of asymptomatic bacteriuria in pregnancy at a teaching hospital. J. Evolution Med. Dent. Sci. 2016;5(57):3951-3955, DOI: 10.14260/jemds/2016/902

\section{INTRODUCTION}

Urinary tract infection is the most frequent medical complication. Urinary tract infection refers to the microbial colonization of the urine and tissue invasion of any structure of urinary tract. ${ }^{1}$ Urinary tract infection may be asymptomatic or symptomatic. Asymptomatic bacteriuria if left untreated might progress to symptomatic urinary tract infection. Females are more susceptible to urinary tract infections due to short urethra. ${ }^{2}$ Pregnant women are two times more

Financial or Other, Competing Interest: None.

Submission 27-05-2016, Peer Review 04-07-2016,

Acceptance 11-07-2016, Published 18-07-2016.

Corresponding Author:

Dr. Indira Guntoory,

Associate Professor,

Department of Obstetrics and Gynaecology,

MIMS, Nellimarla,

Vizianagaram--535217,

Andhra Pradesh.

E-mail: indiraprasadg@gmail.com

DOI: $10.14260 /$ jemds $/ 2016 / 902$ commonly affected than non-pregnant women due to the anatomical and physiological changes that take place in the genitourinary tract. In pregnancy there is dilatation of urinary tract, decrease in the peristalsis of the ureter, decrease in the tone of bladder muscle, decrease in the urine concentration, stasis of urine. These changes put the urinary tract at risk for infections.

The incidence of bacteriuria in pregnant females is the same as that in non-pregnant females. However, recurrent bacteriuria is more common in pregnancy. Pregnancy further enhances the progression of asymptomatic bacteriuria to symptomatic urinary tract infection.

The relationship between asymptomatic bacteriuria in pregnancy with symptomatic urinary tract infection and adverse pregnancy outcomes was first suggested by Kass in 1959.2 Asymptomatic bacteriuria is defined as persistent bacterial colonisation of the urinary tract without urinary symptoms with a colony count of more than 1 lakh colony forming units $/ \mathrm{mL}$ of a single organism. ${ }^{3}$ 
Pregnant women with untreated asymptomatic bacteriuria in early pregnancy have a 20-35\% risk of developing symptomatic urinary tract infection, usually in the form of pyelonephritis in later pregnancy. ${ }^{3}$ Pyelonephritis increases the risk of anaemia, thrombocytopenia, transient renal insufficiency, post-partum endometritis and sepsis in the pregnant women. ${ }^{3}$ Pyelonephritis also increases the risk of premature rupture of membranes, preterm premature rupture of membranes, preterm labour, low birth weight infants, intrauterine growth restriction and foetal mortality. ${ }^{4}$ The treatment of asymptomatic bacteriuria has been shown to reduce subsequent infection by $80-90 \%$ and reduce the incidence of preterm delivery and low birth weight infants. Studies show that screening and treatment of asymptomatic bacteriuria reduces the risk of pyelonephritis in a population with a moderate-to-high prevalence of bacteriuria. ${ }^{5}$

The prevalence of asymptomatic bacteriuria from various studies from the west is in the range of $2-10 \% .6,7$ While in India, it was found to be on the higher side, that is around 4$16 \%{ }^{8-13}$ Routine screening of antenatal women for asymptomatic bacteriuria is now the standard of care in developed countries. However it is not being done routinely in developing counties like India, though several studies have shown that bacteriuria is prevalent in India and in its neighbouring countries. ${ }^{14,15}$ Variations have been observed in the prevalence of asymptomatic bacteriuria and in the sensitivity patterns to antibiotics in different parts of the country. So this study is undertaken to assess the prevalence of asymptomatic bacteriuria, as there are no similar studies in this region.

\section{MATERIAL AND METHOD}

Urine culture and sensitivity is considered to be the gold standard for the diagnosis of asymptomatic bacteriuria of pregnancy.

\section{Study Site}

This is a hospital-based prospective study. This study was conducted in the Department of Obstetrics and Gynaecology at Maharajah's Institute of Medical Sciences, Vizianagaram Dist., Andhra Pradesh from March 2015 to February 2016.

\section{Study Population}

Urine samples were collected from antenatal women attending the antenatal clinic in their first visit irrespective of trimester of pregnancy.

\section{Exclusion Criteria}

1. Women with a history of symptomatic urinary tract infection.

2. Women with abnormalities of urinary tract.

3. Women with other risk factors for urinary tract infection like Diabetes mellitus, Hypertension, other chronic medical disorders, indwelling bladder catheter. ${ }^{4}$ History of usage of antibiotics in the last two weeks.

Approval of Institutional Ethics Committee was taken. The study and the method of collection of urine sample were explained to the antenatal women. Urine samples were collected from the women who gave informed written consent. Information was obtained about age, socioeconomic status, parity, gestational age through a structured questionnaire.

\section{Sampling}

Urine samples were collected by a clean catch midstream specimen of urine into a sterile wide mouthed container with a well-fitted lid. Urine samples were processed within one hour of collection using standard microbiological procedures.

\section{Culturing}

The specimens were cultured on dried plates of MacConkey's agar and sheep blood agar by standard loop method and incubated at $370 \mathrm{C}$ aerobically overnight. After overnight incubation, the plates were read and the organism grown were identified by its growth characteristics on the inoculated media. Incubation was done for further 24 hours if no growth is obtained before a negative report is issued.

\section{Colony Counts}

Samples which showed a bacterial count of $10^{5}$ colony forming units per $\mathrm{mL}$ or more were considered as significant for urinary tract infection. Counts less than $10^{5}$ colony forming units per $\mathrm{mL}$ of urine were considered as insignificant. In case of growth of Staphylococcus aureus, a count of $10^{2}$ colony forming units or more was taken as significant.

\section{Sensitivity Test}

The antibiotic sensitivity pattern of these organisms was determined by the standard Kirby Bauer disc diffusion test of the Clinical and Laboratory Standards Institute and sensitivity to Ampicillin, Ampicillin with Sulbactam, Ceftriaxone, Ceftazidime, Cotrimoxazole, Norfloxacin, Ciprofloxacin, Nitrofurantoin, Nalidixic acid, Amikacin, Gentamicin and Meropenem was tested.

\section{Statistical Analysis}

The results were analysed by SPSS [Statistical Package for Social Services] using mean, median and chi-square test. $P$ value was calculated to assess the association between the variables tested. A P value of less than 0.05 was taken as significant.

\section{Follow-Up}

Culture positive antenatal women were treated with appropriate antibiotics for 7 days' duration. Urine culture was repeated again after 2 weeks of completion of treatment to confirm the clearance of bacteriuria. If the follow-up culture is positive, another course of antibiotics was given based on the sensitivity report.

\section{RESULTS}

A total of 173 samples were screened; 154 women showed no growth on culture; 19 women had significant bacteriuria; 15 women in the age group of 18-25 were culture positive and 4 women in the age group of 26 to 35 years showed culture positivity (Table 1). The youngest women was 18 years of age and the oldest women was 39 years of age; 83 women were multiparous and 11 (57.89\%) women in this group had significant bacteriuria, while only 8 (42.1\%) out of 90 women in the nulliparous group had significant bacteriuria (Table 2). With respect to trimester, 10 (52.63\%) out of 19 culture positive cases were in second trimester in our study. The prevalence rate of $10.98 \%$ was obtained in our study. The commonest organisms isolated were Escherichia coli, Staphylococcus aureus and Klebsiella pneumoniae 
(Table 4). The bacteria grown were most sensitive to Ampicillin+Sulbactam (68\%), Nitrofurantoin (73\%), Amikacin (84\%) and Meropenem (100\%) (Table 5).

\begin{tabular}{|c|c|c|}
\hline $\begin{array}{c}\text { Age Group } \\
\text { in Years }\end{array}$ & $\begin{array}{c}\text { Total Number of } \\
\text { Culture Positive } \\
\text { Women }\end{array}$ & $\begin{array}{c}\text { Total Number of } \\
\text { Women Screened }\end{array}$ \\
\hline $18-25$ & $15(78.94 \%)$ & 137 \\
\hline $26-35$ & $4(21 \%)$ & 33 \\
\hline $36-45$ & - & 3 \\
\hline Total & $\mathbf{1 9}$ & $\mathbf{1 7 3}$ \\
\hline \multicolumn{2}{|c|}{ Table 1: Distribution ofthe Cases in the Study } \\
Population Based on Age
\end{tabular}

Chi-square $=0.41, \mathrm{P}=0.813$

\begin{tabular}{|c|c|c|c|}
\hline Parity & $\begin{array}{l}\text { Number of } \\
\text { Cases with } \\
\text { Significant } \\
\text { Bacteriuria }\end{array}$ & $\begin{array}{c}\text { Number of } \\
\text { Cases } \\
\text { without } \\
\text { Significant } \\
\text { Bacteriuria }\end{array}$ & $\begin{array}{c}\text { Total } \\
\text { Number } \\
\text { of } \\
\text { Pregnant } \\
\text { Women }\end{array}$ \\
\hline Nulliparous & $8(42.1 \%)$ & 82 & 90 \\
\hline Multiparous & $11(57.89 \%)$ & 72 & 83 \\
\hline Total & 19 & 154 & 173 \\
\hline \multicolumn{4}{|c|}{$\begin{array}{c}\text { Table 2: Distribution of Cases in the Study Population } \\
\text { Based on Parity }\end{array}$} \\
\hline
\end{tabular}

Chi-square $=0.84, \mathrm{P}=0.359$

\begin{tabular}{|c|c|c|c|}
\hline Trimester & $\begin{array}{c}\text { Number of } \\
\text { Cases with } \\
\text { Significant } \\
\text { Bacteriuria }\end{array}$ & $\begin{array}{c}\text { Number of } \\
\text { Cases } \\
\text { without } \\
\text { Significant } \\
\text { Bacteriuria }\end{array}$ & $\begin{array}{c}\text { Total } \\
\text { Number of } \\
\text { Pregnant } \\
\text { Women } \\
\text { Screened }\end{array}$ \\
\hline I & 4 & 19 & 23 \\
\hline II & 10 & 100 & 110 \\
\hline III & 5 & 35 & 40 \\
\hline Total & $\mathbf{1 9}$ & $\mathbf{1 5 4}$ & $\mathbf{1 7 3}$ \\
\hline Table 3: Distribution of Cases in the Study Population \\
Based on Trimester \\
\hline
\end{tabular}

Chi-square=1.46, $\mathrm{P}=0.4811$

\begin{tabular}{|c|c|c|}
\hline $\begin{array}{l}\text { Bacterium } \\
\text { Isolated }\end{array}$ & $\begin{array}{l}\text { Number of } \\
\text { Cases (n) }\end{array}$ & $\begin{array}{c}\text { Percentage } \\
(\%)\end{array}$ \\
\hline Escherichia coli & 9 & 47.3 \\
\hline $\begin{array}{l}\text { Staphylococcus } \\
\text { aureus }\end{array}$ & 6 & 31.5 \\
\hline $\begin{array}{c}\text { Klebsiella } \\
\text { pneumoniae }\end{array}$ & 2 & 10.5 \\
\hline Proteus mirabilis & 1 & 5.2 \\
\hline Enterococcus spp. & 1 & 5.2 \\
\hline Total & 19 & 99.7 \\
\hline \multicolumn{3}{|c|}{$\begin{array}{l}\text { Table 4: Distribution of Culture Positive Cases } \\
\text { According to the Bacterium Isolated }(n=19)\end{array}$} \\
\hline
\end{tabular}

Contaminants-2 cases

\begin{tabular}{|c|c|c|c|c|}
\hline $\begin{array}{c}\text { Sensitivity to } \\
\text { Antibiotic }\end{array}$ & $\begin{array}{c}\text { Number of Cases } \\
\text { Sensitive (n) }\end{array}$ & $\begin{array}{c}\text { Number of Cases } \\
\text { Sensitive (\%) }\end{array}$ & $\begin{array}{c}\text { Number of Cases } \\
\text { Resistant (n) }\end{array}$ & $\begin{array}{c}\text { Number of Cases } \\
\text { Resistant (\%) }\end{array}$ \\
\hline Ampicillin & 1 & 5 & 18 & 94 \\
\hline $\begin{array}{c}\text { Ampicillin } \\
\text { +Sulbactam }\end{array}$ & 13 & 68 & 6 & 31 \\
\hline Ceftriaxone & 9 & 47 & 10 & 52 \\
\hline Ceftazidime & 6 & 31 & 13 & 68 \\
\hline Cotrimoxazole & 5 & 26 & 5 & 73 \\
\hline Nitrofurantoin & 14 & 73 & 15 & 26 \\
\hline Norfloxacin & 4 & 21 & 12 & 63 \\
\hline Ciprofloxacin & 7 & 36 & 18 & 94 \\
\hline Nalidixic acid & 1 & 5 & 7 & 36 \\
\hline Gentamicin & 12 & 63 & 3 & 15 \\
\hline Amikacin & 16 & 84 & Nil & Nil \\
\hline Meropenem & 19 & 100 & & \\
\hline \multicolumn{2}{|c|}{ Table 5: Distribution of Antibiotic Sensitivity and Resistance of Culture Positive Cases (n=19) } \\
\hline
\end{tabular}

\section{DISCUSSION}

A total of 173 antenatal women were screened for asymptomatic bacteriuria of pregnancy; $78 \%$ of the women screened belonged to a lower socioeconomic status. This is in concordance with the study done by B. Prasanna et $\mathrm{al}^{16}$ and Lavanya SV et al ${ }^{11}$ This establishes that lower socioeconomic status is a risk factor for asymptomatic bacteriuria of pregnancy. Women in the age group of 18 to 25 years had a higher incidence of asymptomatic bacteriuria in the present study. This is comparable with the studies done by Sujatha $\mathrm{R}$ et $\mathrm{al}^{12}$ and Alghalibi et $\mathrm{al}^{17}$ This may be due to this group being highly sexually active and the trauma caused by the movement of penis in the vagina. The observed trend in this study and other studies is that the age group of 18 to 35 years is a high risk group for asymptomatic bacteriuria of pregnancy. However, the association between age group and asymptomatic bacteriuria was not statistically significant in this study. In a study by Lavanya SV et al ${ }^{11}$, the prevalence was higher in the less than 20 years' age group.
In the present study, 11 out of 19 (57.89\%) women with significant bacteriuria were multigravidae with a prevalence rate of $13.25 \%$. This is in concordance with the studies done by CA Turpin et al (16\%). ${ }^{18}$ and B. Prasanna et al ${ }^{16}$ The chisquare test of association between parity and asymptomatic bacteriuria showed no significant difference; $52.63 \%$ of culture positive cases occurred in second trimester, $26 \%$ in third trimester and $21 \%$ in first trimester respectively in our study. This compares well with the studies done by Obirikorang $\mathrm{C}$ et al ${ }^{19}$, Alghalibi et $\mathrm{al}^{17}$, Girish Babu RJ et al ${ }^{9}$ This may be due to more number of women reporting to the hospital in early second trimester and the anatomical and physiological changes in the urinary tract becoming more pronounced with advancing gestational age. However, the association between trimester and asymptomatic bacteriuria was not statistically significant. A higher prevalence was found in the third trimester in a study by B. Prasanna et al 16 This conforms that $80 \%$ of women with asymptomatic bacteriuria can be detected by a single urine culture and sensitivity at 
12-16 weeks. An additional $2 \%$ of women can be detected by urine culture repeated later on. Negative urine culture in early pregnancy is directly related to the absence of cystitis and pyelonephritis in later pregnancy. ${ }^{20}$

The prevalence rate of asymptomatic bacteriuria of pregnancy in the present study was found to be $10.98 \%$. This is comparable with the prevalence rate in studies done by Girish Babu RJ et al (10\%). ${ }^{9}$ and C. Obirikorang et al (9.5\%). ${ }^{19}$ The prevalence rate obtained in the present study $(10.98 \%)$ was a little higher than that obtained by Lavanya SV et al ${ }^{11}$ (8.4\%), Sujatha R et al12 (7.3\%). This may be due to the variation in the population studied, their socioeconomic status, frequency of sexual activity, hygienic practices and health care during pregnancy. The causative organisms usually associated with urinary tract infection are members of gastrointestinal tract and vaginal flora. The commonest bacterium isolated was Escherichia coli (47\%). This is in concordance with the studies done by Lavanya SV et al ${ }^{11}$, Sujatha $\mathrm{R}$ et al ${ }^{12}(77 \%)$, B. Prasanna et $\mathrm{al}^{16}(62 \%)$, Obirikorang $\mathrm{C}$ et $\mathrm{al}^{19}(36.8 \%)$. Pregnancy was shown not to abolish the difference in virulence between Escherichia coli causing acute pyelonephritis and asymptomatic bacteriuria as shown in the studies by Stenqvist $\mathrm{K}$ et $\mathrm{al}^{21}$. Pathak $\mathrm{A}$ et $\mathrm{al}^{22}$ in their study observed that the risk factors for the carriage of multidrug resistant Escherichia coli were graduate or post graduate education, self-employed status, a family size of more than ten, antibiotic usage in the last 4 weeks and history of hospitalization in the last 4 weeks. Escherichia coli grown in the present study were found sensitive to Amikacin, Gentamicin, Ampicillin with Sulbactam and Nitrofurantoin.

Ampicillin with Sulbactam can be given during pregnancy when necessary. Amikacin and Gentamicin have to be given with caution during pregnancy, as they are associated with nephrotoxicity and ototoxicity. Nitrofurantoin may cause haemolysis in a glucose-6-phosphate deficient infant when used close to term. The other organisms isolated were Staphylococcus aureus (31.57\%), Klebsiella pneumoniae (10.5\%), Proteus mirabilis (5.2\%) and Enterococcus species (5.2\%). The bacteria grown were sensitive to Ampicillin with Sulbactam (68\%), Nitrofurantoin (73\%), Amikacin (84\%). All the samples were sensitive to Meropenem (100\%). This correlates well with the studies done by B. Prasanna et al ${ }^{16}$, Girish Babu RJ et al ${ }^{9}$ All the bacteria were resistant to Ampicillin except Enterococcus. This increasing resistance to antibiotics may be due to self-medication, indiscriminate use of antibiotics, empirical treatment without doing culture and sensitivity, usage of antibiotics for inadequate length of time. Empirical treatment should be discouraged as the causative organisms and their sensitivity pattern is different for different population groups. The use of urine microscopy as a means of screening for urinary tract infection was found to be nonspecific. So urine culture and sensitivity must be done in all antenatal women.

The drawback with urine culture and sensitivity is that it takes 48 hours for the report and the woman may not turn up with the report for treatment. Treatment should be instituted as early as possible in pregnant women with asymptomatic bacteriuria to forestall complications. Consideration of local resistance rates is necessary while choosing the antibiotic and the duration of treatment. The safety profile of the antibiotic needs to be considered for treatment of asymptomatic bacteriuria due to the risk of adverse effects on the foetus.
Though optimal length of therapy is controversial, 3 to 7 days' duration of treatment gives greater eradication rates. ${ }^{3}$ Urine culture and sensitivity should be repeated after a course of antibiotic to demonstrate the clearance of bacteriuria.

At least one further screening should be conducted postnatally. One of the patients in our study who was treated for asymptomatic bacteriuria in first trimester on follow-up developed symptomatic urinary tract infection in third trimester due to another organism. Recurrence with the same organism or failure to eliminate is indicative of renal parenchymal infection or structural abnormality. ${ }^{23}$ Universal urine screening for pregnant women is cost effective if the prevalence of asymptomatic bacteriuria is greater than $2 \%$ and the cost of the screening tests was less than 26 US\$. ${ }^{24}$ Screening and treatment of asymptomatic bacteriuria during antenatal period was suggested by Adam et al 25 as one of the most cost effective interventions at the primary level of health care system to achieve the millennium development goals for health.

\section{CONCLUSION}

Asymptomatic bacteriuria being a subclinical infection, one has to actively look for it by incorporating urine culture and sensitivity in the routine antenatal investigations. The pregnant women should be educated about maintaining genital hygiene and cleaning their genitalia and perineum after passing urine and defecation. This goes a long way in reducing maternal and foetal morbidity and mortality.

\section{ACKNOWLEDGEMENT}

We thank the Chairman of MIMS, Superintendent, H.O.D. of Dept. of Obstetrics and Gynaecology, H.O.D. of Dept. of Microbiology and Staff of Microbiology lab and all the participants of this study for their co-operation.

\section{REFERENCES}

1. Wyngaarden JB, Simth LH, Bennett JC, eds. Cecil Text book of medicine. Hospital acquired infections. 19 th $\mathrm{edn}$. Philadelphia: WB Saunders 1992:593-7.

2. Kass EH. Bacteriuria and pyelonephritis of pregnancy. Arch Interna Med 1960;105:194-8.

3. Nicolle LE, Bradley S, Colgan R, et al. Infectious diseases society of America guidelines for the diagnosis and treatment of asymptomatic bacteriuria in adults. Clin Infect Dis 2005;40(5):643-54.

4. Uncu Y, Uncu G, Esmer A, et al. Should asymptomatic bacteriuria be screened in pregnancy? Clin Exp Obstet Gynecol 2002;29:281-5.

5. Gratacos E, Torres PJ, Vila J, et al. Screening and treatment of asymptomatic bacteriuria of pregnancy to prevent pyelonephritis. J Infect Dis 1994;169(6):1390-2.

6. Schnarr J, Smaill F. Asymptomatic bacteriuria and symptomatic urinary tract infections in pregnancy. Euro J Clin Invest 2008;38(Suppl 2):50-75.

7. Teppa RJ, Roberts JM. The uriscreen test to detect significant asymptomatic bacteriuria during pregnancy. J Soc Gynecol Investig 2005;12(1):50-3.

8. Jain V, Das V, Agarwal A, et al. Asymptomatic bacteriuria and obstetric outcome following treatment in early versus late pregnancy in north Indian women. Indian J Med Res 2013;137(4):753-8. 
9. Girishbabu RJ, Srikrishna R, Ramesh ST. Asymptomatic bacteriuria in pregnancy. Int $\mathrm{J}$ Biol Med Res 2011;2(3):740-2.

10. Bandhopadhyay S, Thakur JS, Ray P, et al. High prevalence of bacteriuria in pregnancy and its screening methods in north India. J Indian Med Asso 2005;103(5):259-62.

11. Lavanya SV, Jogalaxmi D. Asymptomatic bacteriuria in antenatal women. Ind J Med Microbiol 2002;20(2): 105-6.

12. Sujatha $R$, Nawani M. Prevalence of asymptomatic bacteriuria and its antibacterial susceptibility pattern among pregnant women attending the antenatal clinic at Kanpur, India. JCDR 2014;8(4):DC01-3.

13. Chandel LR, Kanga A, Thakur K, et al. Prevalence of pregnancy associated asymptomatic bacteriuria: a study done in a tertiary care hospital. J Obstet and Gynaecol of India 2012;62(5):511-4.

14. Khattak AM, Khattak S, Khan $\mathrm{H}$, et al. Prevalence of asymptomatic bacteriuria in pregnant women. Pak J Med Sci 2006;22(2):162-6.

15. Ullah MA, Barman A, Siddique MA, et al. Prevalence of asymptomatic bacteriuria and its consequences in pregnancy in a rural community of Bangladesh. Bangladesh Med Res Counc Bull 2007;33(2):60-4.

16. Prasanna B, Naimisha M, Swathi K, et al. Prevalence of asymptomatic bacteriuria in pregnant women, isolates and their culture sensitivity pattern. Int J Curr Microbiol App Sci 2015;4(8):28-35.

17. Alghalibi SM, Al-Jaufy A, Al Moayad E. Bacterial urinary tract infection among pregnant women in Sana's cityYemen. Arab Gulf Journal of Scientific Research 2007;25:23-31.
18. Turpin CA, Minkah B, Danso KA, et al. Asymptomatic bacteriuria in pregnant women attending antenatal clinic at komfo anokye teaching hospital Kumasi, Ghana. Medical Journal 2007;41(1):26-9.

19. Obirikorang C, Quaye L, Bio FY, et al. Asymptomatic bacteriuria among pregnant women attending antenatal clinic at the university hospital Kumasi, Ghana. Journal of Medical and Biomedical Sciences 2012;1(1):38-44.

20. Golan A, Wexler S, Amit A, et al. Asymptomatic bacteriuria in normal and high risk pregnancy. Eur J Obstet Gynaecol Reprod Biol 1989;33(2):101-8.

21. Stenqvist K, Sandberg T, Janson LG, et al. Virulence factors of Escherichia coli in urinary isolates from pregnant women. J Infect Dis 1987;156(6):870-7.

22. Pathak A, Chandran SP, Mahadik K, et al. Frequency and factors associated with the carriage of multidrug resistant commensal Escherichia coli among women attending antenatal clinics in central India. BMC Infect Dis 2013;13:199.

23. Patterson TF, Andriole VT. Detection, significance and therapy of bacteriuria in pregnancy. Update in the managed health care era. Infect Dis Clin North Am 1997;11(3):593-608.

24. Wadland WC, Plante DA. Screening for asymptomatic bacteriuria in pregnancy. A decision and cost analysis. J Fam Pract 1989;29(4):372-6.

25. Adam T, Lim SS, Mehta S, et al. Achieving the millennium development goals for health- cost effectiveness analysis of strategies for maternal and neonatal health in developing countries. BMJ 2005;331(7525):1107-12. 